\title{
SUBLITTORAL ALGAL POPULATION IN PORT ERIN BAY, ISLE OF MAN
}

\author{
By Elsie M. BurRows \\ Department of Botany, Liverpool University
}

(Text-fig. I)

In recent years much information has accumulated on the composition and distribution of algal populations in the Isle of Man, with increased knowledge of their ecological relationships (Knight \& Parke, I93I, I950; Jones, I948; Lodge, 1948, I954; Burrows \& Lodge, 1949, I951; Southward, 1953). This, however, has mostly come from studies made in the intertidal region, and even here many problems remain for which, at present, no satisfactory explanation can be found. The mostdifficult of these, perhaps, relates to the appearance of algal species for a limited period of the year only: it is not known where and in what form their life-histories are continued for the rest of the year. The littoral and sublittoral regions are known to have many species in common. This means that the differences between the regions, as environments for the growth of algae, can be bridged by the plasticity of the species concerned. It seemed likely, therefore, that a detailed study of the sublittoral algal populations might help towards an understanding of the ecology of both regions and also of the interactions between them.

Attempts have been made by several workers using diving equipment to find the exact distribution of sublittoral algae (Kitching, Macan \& Gilson, I934; Bursa \& Wojtusiak, 1939, I948; Waern, I952; Forster, 1955, 1958; Aleem, 1956), but the scope of such work is limited at present. Walker (1947) made surveys of sublittoral algae around the coast of Scotland using a specially designed view-box for inspection of the sea floor and a calibrated spring grab for collecting samples from fixed points, and was able to make quantitative estimates of the distribution of the larger brown algae over a wide area.

In August I955 a survey of the sublittoral algae of Port Erin Bay was begun using a combination of the techniques mentioned above. The bay is approximately half a mile square and partially bounded on the seaward end by a broken breakwater. On the north and south the sides are rocky, while most of the floor of the bay is sandy. From the beach at the eastern end to the breakwater and open sea on the west, the bay shelves gradually to a depth of $12 \mathrm{~m}$. The deepest part lies in the angle formed by the breakwater and the south shore and reaches a depth of $14 \mathrm{~m}$. The limit of the sublittoral 
rock surface was determined in 1956 by echo-sounding. The limit was taken as the point at which the steeply sloping side of the bay turned abruptly to the horizontal. As far as possible this was checked by direct observation but, at the time this work was carried out, the water was not very clear. Tidal currents enter the bay on the north side and swing round towards the south, but little is known about water movement on the floor of the bay. The area was sampled by means of a spring grab of the type used by Walker (1947). It took algae from a square of side $75 \mathrm{~cm}$ and was used much in the same way that an ecologist on land uses a quadrat as a sampling unit. The grab was worked from the motor-boat 'Cypris' and, for each sample taken, the boat position was determined by taking sextant readings on to accurately charted points on the shore. Depths were measured with a lead line, and, so that it would be possible to relate all depths to a fixed tide level, simultaneous readings were made on a tide-staff on the harbour wall for all periods over which samples were taken in the bay. Through an analysis of the samples it was hoped to work out the over-all distribution of the algae. The action of the grab was watched through the very calm clear water, and observations on its action on different types of substrate were also made by a diver using an aqualung. On a number of occasions the diver completed clearance of squares incompletely cleared by the grab. In this way it was found that the grab did not always give a complete clearance of the sample squares and undoubtedly a good deal was missed, but the method had the advantage that, for the algae collected, the exact positions in which they were growing were determined.

Because of the extremely favourable weather conditions in 1955, the survey proved to be much easier than had been anticipated. The water was so calm and clear that the major beds could easily be seen through a glass-bottomed bucket and their limits were plotted from a rowing boat with the help of a sextant. The survey was repeated in August 1956 using the same general methods, and I 25 samples were taken on each occasion.

\section{DISTRIBUTION OF THE SUBLITTORAL ALGAE}

It was found that there were two distinct algal vegetation regions in the sublittoral, associated with the two main types of substrate, continuous rock surface and sand. The bay floor consists mainly of sand overlaid by stones and boulders of varying sizes; in places these lie close together in large groups, in other places they are widely scattered and often partially buried in the sand. No doubt much movement of stones and boulders occurs on the sea bed at some seasons of the year, but many boulders brought up by dredge and grab appeared to have been buried for some time and supported growths of algae only on one surface. Certain large groups of boulders are conspicuous at all times of the year as a result of the weed they carry. An 
analysis of the composition of the vegetation associated with the two regions is given in Table I. Only those species, the identification of which is certain, have been included. Herbarium specimens of the algae collected during the survey have been deposited in the herbarium of the Botany Department of Liverpool University. The names used are those in Parke's check-list (I953), with later corrections (Parke, 1956, 1957).

\section{The vegetation of the continuous rock surface}

The algae attached to the rock surface form a more or less permanent population conspicuous at all times of the year. In this population Laminaria digitata, L. saccharina, L. hyperborea and Saccorhiza polyschides are the dominant plants, with many smaller algae present either on the rock surface or as epiphytes on the stipes of Laminaria hyperborea. Table I distinguishes the species found in this population. The L. hyperborea plants had an average age of $6 \pm 2$ years, as determined by counting the numbers of growth-rings at the base of the stipe (Parke, unpublished). The maximum age was 8 years. The population extended downwards to a depth of $12 \mathrm{~m}$ and appeared to be limited by the absence of continuous rock below this level. Forster (1955) records $L$. hyperborea as extending down to, and disappearing below, $17 \mathrm{~m}$ in the vicinity of Stoke Point rocks, Devon.

\section{The vegetation of the floor of the bay}

An extensive population, which was more or less loose-lying, was found on the floor of the bay and covering the greater part of its area. The dominant species were L. saccharina, Saccorhiza polyschides, Chorda filum and Desmarestia aculeata. The substrates available for attachment in this region consist of sand grains, loose pieces of shell, stones of various sizes, small boulders and other algae. Probably in the first instance most of the algae belonging to this population are attached, perhaps only to sand grains, but at the time that this survey was made, many of them showed no sign of having had an attachment. In the case of Laminaria saccharina, the haptera had many branches, but the ends were quite free or intertwined with other algae. Such haptera were, on the whole, smaller than those found for attached plants. Sometimes each hapteron branch was attached to a separate small pebble or piece of broken shell. Many of the smaller algae were found in tangled masses, and in some cases a definite adhesion had been formed so that the plants stuck firmly together. Notable in this respect were the adhesions made by the thalli of Dictyota dichotoma and Plocamium coccineum, both to other algae and also to stones. Once attached in this way, the fronds of Dictyota are able to grow forming flat expanded sheets.

Much of the loose-lying population was at a depth of IO-I4 m, but it extended into shallower water. It disappeared, however, where the depth of the 
TABLE 1. LIST OF ALGAE FOUND DURING THE SUBLITTORAL SURVEYS 1955 AND 1956

Species

Laminaria hyperborea (Gunn.) Fosl.

L. digitata (Huds.) Lamour.

L. saccharina (L.) Lamour.

Saccorhiza polyschides (Lightf.) Batt.

Chorda filum (L.) Stackh.

Desmarestia aculeata (L.) Lamour.

Sphacelaria pennata (Huds.) Lyngb.

Dictyota dichotoma (Huds.) Lamour.

Ulva lactuca L.

Phycodrys rubens (Huds.) Batt.

Rhodymenia palmata (L.) Grev.

Membranoptera altata (Huds.) Stackh.

Ceramium rubrum (Huds.) Ag.

Ptilota plumosa (Huds.) Ag.

Plocamium coccineum (Huds.) Lyngb.

Delesseria sanguinea (Huds.) Lamour.

Cryptopleura ramosa (Huds.) Kylin

Callophyllis laciniata (Huds.) Kütz.

Callocolax neglectus Schm.

Lithothamnion, etc.

Chondrus crispus (L.) Stackh.

Cladophora rupestris (L.) Kütz.

Sorocarpus micromorus (Bory) Silva

Rhodomela confervoides (Huds.) Silva

Odonthalia dentata (L.) Lyngb.

Brongniartella byssoides (Good. et Woodw.) Schm.

Polysiphonia violacea (Roth) Grev.

Hypoglossum woodwardii Kütz.

Gigartina stellata (Stackh.) Batt.

Fucus serratus L.

Lomentaria articulata (Huds.) Lyngb.

Phyllophora membranifolia (Good. et Woodw.) J. Ag.

Apoglossum ruscifolium (Turn.) J. Ag.

Gelidium latifolium (Grev.) Born. et Thor.

Polysiphonia elongata (Huds.) Harv.

$P$. nigrescens (Huds.) Grev.

Corallina officinalis $\mathrm{L}$.

Litosiphon pusillus (Carm.) Harv.

Plumaria elegans (Bonnem.) Schm.

Pterosiphonia complanata (Clem.) Fkbg.

Antithamnion sarniense (Lyle) G. Feldm.

Chaetomorpha melagonium (Web. et Mohr) Kütz.

Fucus vesiculosus L.

Halidrys siliquosa (L.) Lyngb.

Polysiphonia urceolata (Dillw.) Grev.

Ectocarpus confervoides (Roth) Le Jol. s. lat.

Cruoria pellita (Lyngb.) Fries

Ceramium diaphanum (Lightf.) Roth

Stictyosiphon subarticulatus (Aresch.) Reinke

Chylocladia verticillata (Lightf.) Bliding

Asparagopsis armata Harv., tetrasporophyte

Enteromorpha compressa (L.) Grev.

E. clathrata (Roth) Grev.

Cystoclonium purpureum (Huds.) Batt.
Percentage occurrence in samples

\begin{tabular}{|c|c|c|c|}
\hline \multicolumn{2}{|c|}{$\begin{array}{c}\text { Rock surface } \\
\text { population }\end{array}$} & \multicolumn{2}{|c|}{$\begin{array}{l}\text { Loose-lying } \\
\text { population }\end{array}$} \\
\hline I955 & 1956 & I955 & 1956 \\
\hline 74 & 72 & - & 5 \\
\hline 24 & 5 & 4 & \\
\hline 32 & 40 & 96 & 52 \\
\hline 40 & 43 & 38 & 30 \\
\hline 2 & 3 & 40 & 37 \\
\hline 4 & 12 & 80 & 43 \\
\hline 4 & IO & 62 & 34 \\
\hline 4 & 17 & 60 & 35 \\
\hline 26 & I5 & 44 & 25 \\
\hline 78 & 63 & 38 & 16 \\
\hline 70 & 60 & 56 & I4 \\
\hline 54 & 63 & IO & 7 \\
\hline 42 & 25 & 44 & I6 \\
\hline 46 & 33 & 4 & 7 \\
\hline 20 & 25 & 72 & 30 \\
\hline 20 & 7 & 20 & Io \\
\hline I8 & 53 & 28 & I6 \\
\hline 38 & 17 & 30 & 26 \\
\hline 4 & - & 2 & - \\
\hline 36 & 27 & I4 & 4 \\
\hline I4 & 3 & 2 & 6 \\
\hline IO & 7 & 2 & 8 \\
\hline IO & 3 & I6 & - \\
\hline 8 & 17 & 30 & 26 \\
\hline 8 & IO & IO & 8 \\
\hline 8 & 12 & 36 & $3 I$ \\
\hline 8 & - & I6 & I \\
\hline 6 & 7 & 8 & IO \\
\hline 6 & 5 & IO & 5 \\
\hline 6 & 7 & 4 & 6 \\
\hline 6 & 3 & 6 & I \\
\hline 6 & 3 & 2 & - \\
\hline 6 & I5 & - & - \\
\hline 6 & I3 & - & I \\
\hline 6 & - & 30 & IO \\
\hline 6 & - & I6 & 6 \\
\hline 4 & 5 & 2 & - \\
\hline 4 & - & 4 & IO \\
\hline 2 & 7 & 2 & 4 \\
\hline 2 & 3 & I 8 & 7 \\
\hline 2 & 4 & 44 & - \\
\hline 3 & 12 & - & 2 \\
\hline 2 & 3 & - & 2 \\
\hline 2 & - & - & 2 \\
\hline 2 & I7 & - & 4 \\
\hline 2 & - & 4 & I \\
\hline 2 & - & - & - \\
\hline 2 & - & - & - \\
\hline 2 & - & 二 & 5 \\
\hline 2 & - & 二 & \\
\hline 2 & - & E & -1 \\
\hline $\begin{array}{l}2 \\
2\end{array}$ & - & 2 & - \\
\hline- & 25 & I2 & 20 \\
\hline
\end{tabular}


TABLE 1 (cont.)

Species

Heterosiphonia plumosa (Ellis) Batt.

Cladostephus verticillatus (Lightf.) Ag.

Ahnfeltia plicata (Huds.) Fries

Alaria esculenta (L.) Grev.

Chondria dasyphylla (Woodw.) Ag.

Spermothamnion repens (Dillw.) K. Rosenv.

Chordaria flagelliformis (Müll.) Ag.

Griffithsia flosculosa (Ellis) Batt.

Calliblepharis ciliata (Huds.) Kütz.

Nitophyllum punctatum (Stackh.) Grev.

Bonnemaisonia asparagoides (Woodw.) Ag., sexual plant

Gracilaria verrucosa (Huds.) Papenf.

Sporochnus pedunculatus (Huds.) Ag.

Ceramium tenuissimum (Lyngb.) J. Ag.

Bonnemaisonia hamifera Hariot, tetrasporophyte,

Naccaria wiggii (Turn.) Endl.

sexual plant

Polysiphonia nigra (Huds.) Batt.

Cutleria multifida (Sm.) Grev.

Corynospora pedicellata (Sm.) J. Ag.

Arthrocladia villosa (Huds.) Duby

Seirospora griffithsiana Harv.

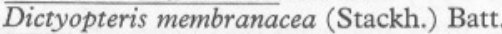

Polysiphonia spiralis Batten

Isthmoplea sphaerophora (Carm.) Kjellm.

Porphyra umbilicalis (L.) Kütz.

Enteromorpha linza (L.) J. Ag.

Furcellaria fastigiata (L.) Lamour.

Dumontia incrassata (Müll.) Lamour.

Spongonema tomentosum (Huds.) Kütz.

Asperococcus bullosus Lamour.

Scytosiphon lomentaria (Lyngb.) Endl.

Myrionema strangulans Grev.

Tilopteris mertensii (Sm.) Kütz.

Callithamnion tetragonum (Wither.) Ag.

Polyides caprinus (Gunn.) Papenf.

Holmsella pachyderma (Reinsch) Sturch

Chaetopteris plumosa (Lyngb.) Kütz.

Halarachnion ligulatum (Woodw.) Kütz.

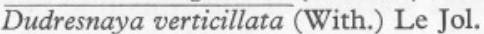

Sphondylothamnion multifidum (Huds.) Näg.

Percentage occurrence in samples

\begin{tabular}{|c|c|c|c|}
\hline \multicolumn{2}{|c|}{$\begin{array}{l}\text { Rock surface } \\
\text { population }\end{array}$} & \multicolumn{2}{|c|}{$\begin{array}{l}\text { Loose-lying } \\
\text { population }\end{array}$} \\
\hline I955 & I956 & I955 & I956 \\
\hline- & 7 & 2 & I \\
\hline- & 3 & 4 & I \\
\hline- & 3 & 8 & 7 \\
\hline - & 7 & 一 & 2 \\
\hline - & 5 & - & 5 \\
\hline - & 3 & - & $\begin{array}{l}6 \\
2\end{array}$ \\
\hline Z & 3 & - & 2 \\
\hline - & $\begin{array}{l}3 \\
3\end{array}$ & - & 1 \\
\hline- & 3 & - & - \\
\hline - & - & I8 & 7 \\
\hline- & - & I6 & 4 \\
\hline- & - & I6 & I \\
\hline- & - & I4 & I \\
\hline- & - & IO & I \\
\hline- & - & 2 & - \\
\hline- & - & 4 & - \\
\hline- & - & 4 & - \\
\hline- & - & 2 & I \\
\hline- & - & 2 & - \\
\hline- & - & 2 & - \\
\hline- & - & 2 & - \\
\hline- & - & 2 & - \\
\hline- & - & 2 & - \\
\hline - & - & 2 & - \\
\hline - & - & 2 & - \\
\hline - & - & 2 & - \\
\hline- & - & - & 4 \\
\hline - & - & - & $\begin{array}{l}2 \\
2\end{array}$ \\
\hline - & - & E & $\begin{array}{l}2 \\
2\end{array}$ \\
\hline - & $\bar{Z}$ & 二 & $\begin{array}{l}2 \\
\mathrm{I}\end{array}$ \\
\hline- & - & - & I \\
\hline- & - & - & I \\
\hline - & - & - & I \\
\hline - & - & - & I \\
\hline - & - & - & I \\
\hline- & - & - & I \\
\hline- & - & - & I \\
\hline- & - & - & I \\
\hline- & - & - & I \\
\hline
\end{tabular}

The species underlined were found only in the loose-lying population and below $8 \mathrm{~m}$.

water was less than $4 \mathrm{~m}$ at low tide. This fact will be referred to again later.

It has not been possible to identify with certainty all the algae found in the loose-lying population; some belong to genera in which the separation of species is at present extremely difficult, while others lack the reproductive stages necessary for identification. Of the eighty-eight species so far identified, 
fifty-seven were also found growing in the permanent sublittoral population on the rock surface, many were also known to occur in the intertidal region, but eleven were found exclusively in the loose-lying population (see Table I). The algae belonging to this last group of obligate sublittoral species occurred only in the deeper part of the bay and were not found at a depth of less than $8 \mathrm{~m}$, measured at low tide. Some of the plants found in the loose-lying population, but not in the permanent, are also known to occur in the intertidal region and may have been washed down into the sublittoral, but they appeared quite healthy and many were fruiting. The question as to how far these algae, which were also found in the intertidal region, could be regarded as having developed in the loose-lying population or to have been washed into it during the summer, is not easily answered. Occasional plants of Laminaria saccharina showed evidence of having been torn from a rock surface, but the vast majority gave no sign of ever having been attached. It will be shown later that sand grains can give an attachment for algal reproductive bodies sufficient to allow them to segment and develop into new plants. In some cases no further attachment is necessary. In the loose-lying population there was a notable absence of many of the intertidal algae, such as Ascophyllum nodosum, Pelvetia canaliculata and Fucus species, except for $F$. serratus which was present in a very broad form at 4-7 $\mathrm{m}$ depth. Laminaria hyperborea, which is also often washed up on to the shore in quantity, was absent from the loose-lying population of 1955 and almost so in 1956 . Probably owing to the calm weather of 1955 , little material had been added from the intertidal region; but, in rougher weather, it seems likely that the latter region would add considerably to the loose-lying population. In this survey, interest centred, not so much in making a species list for the sublittoral algae as in finding out something about their ecological relationships. In April 1955, a dredge haul was taken across Port Erin Bay in a direction which would have passed right through the loose-lying population. On this occasion no algae at all were found. This might have been the result of temporarily unfavourable conditions, the water temperature being very low following two very cold winters and a very cool summer in 1954. In the months following April 1955, there was a period of very calm seas, and sediment settled giving very clear water. The more intense light and warmth of the sunshine passing through the clear water gave ideal conditions for the development of sublittoral algae and an extensive population was found here at the end of August.

The lack of disturbance of the sea bed in this particular year was well illustrated by the form of Saccorhiza polyschides growing in this region. On the rock surface in shallower water, the fronds were split into several fingers, but loose-lying plants from a depth of ro $\mathrm{m}$ showed very little splitting of the frond.

It seemed obvious that with any disturbance of the bottom waters, much of the loose-lying population would be washed in and this was observed 
towards the end of the period of the survey. On 2 September, a south-westerly wind sprang up and waves began to break on the rocks on the north side of the bay. During the following $24 \mathrm{~h}$ an appreciable quantity of sea-weed had been washed up beyond the tide line and trials with the grab suggested that some shifting of the central mass had taken place. Attempts to replot the positions of the weed beds, by visual means, failed because sand in the water obscured the view. An enormous quantity of sand was stirred up and its suspension noticeably altered the colour of the water. The heavier particles would settle rapidly, but finer material would continue to restrict the penetration of light to the sea bed for a considerable time. During the next $24 \mathrm{~h}$ the wind had again increased and small boulders and stones were washed in with attached weeds.

An analysis of the algae brought in during the first $24 \mathrm{~h}$ of the gale showed that it came from three sources: (I) the intertidal region, (2) the sublittoral attached population, (3) the sublittoral loose-lying population. Thus it is seen that under the very favourable conditions of 1955 , an extensive, more or less loose-lying population was developed on the floor of Port Erin Bay and that this remained undisturbed through the prolonged calm weather of the summer. As soon as storms came, bringing about movement of the bottom waters, a considerable quantity of weed from this population was carried inshore, but the disturbance failed to remove all of it. At the end of November 1955, there was an appreciable quantity left, but the plants were very broken and rotting. Grab and dredge samples taken at intervals during the winter months showed that many fragments of algae were still present at the end of January. Many of these had begun to proliferate new branches, some of the latter primarily concerned with asexual reproduction, others giving vigorous vegetative growth. Examples of this will be discussed later.

Patches of large boulders give a firm substrate for sublittoral algae in several parts of the bay and these may be conspicuous at all times of the year. One such large patch occurs in the centre of the bay in such a position that a part of it may occasionally just be exposed to the air at extreme low water of spring tides. The distinction between patches of this kind and the general loose-lying population is only one of degree. The stability of any part of the population depends on the size and also on the firmness of the substrate and the degree of water movement.

Naylor (1955), working on species of Idotea (Isopoda), found large numbers of these animals feeding on decaying sea-weed in the deep corner of the bay in the angle formed by the south shore and the breakwater. It seems likely, bearing in mind the direction of tidal currents within the bay, that there is a general tendency for the bottom algae to be washed, perhaps very slowly, into this corner where they decay. Grab samples attempted in this position in March 1956 brought up no healthy plants, but many decaying fragments in the mesh of the grab net, and large numbers of Idotea. 


\section{Conditions in 1956}

Unlike the summer of 1955 that of 1956 was stormy and lacking in sunshine. The same general distribution of sublittoral algae was found, but with some significant differences in the second year.

(I) The extent of the loose-lying population was distinctly less than in the previous August and its position was different. Whereas in 1955 the population extended over the major part of the sand of the bay, in 1956 a continuous cover of large algae was only found in shallower water. Elsewhere in the bay algae were present in more scattered patches. Many algae had already been washed up on to the beach and much of the tangled mass in shallow water had probably started life deeper down and been brought inshore by water movement.

(2) There was a considerable difference in the size of the plants of Saccorhiza polyschides. In I955, the majority of the plants found were very large, with well-formed holdfast 'bells' and many with stipes winged and releasing zoospores. In 1956 , no mature plants were found; the majority were in the sporeling stage with the bells just beginning to form as small rims on the stipe. The largest bells were little more than half the size of that of an adult plant. It is certain that adult plants, if formed, would have been lost more easily than sporelings, but it is unlikely that none at all would have remained on the floor of the bay. Since no adult plants at all were found in the samples at the end of August, it is likely that the whole population was at an earlier stage of development and this could have been the result of less favourable conditions for growth during this season.

(3) The species composition of the loose-lying population in 1956 was not identical with that of 1955, and many species showed an increase or decrease in quantity between the years. Gracilaria verrucosa, Sporochnus pedunculatus and Antithamnion sarniense, all present in quantity in the deeper parts of the bay in 1955, were quite rare in 1956. Desmarestia aculeata also showed a marked decrease in bulk, though it was present in fair quantity in I956. On the other hand, Brongniartella byssoides, found as only occasional plants in I955, had increased considerably the following year. These differences may have resulted from the deficiencies of the sampling method, but the general impression gained by those working on the survey in both years was that there was a very distinct difference in the species composition, particularly of the loose-lying populations, between the years. At present there is little information concerning the way in which environmental factors affect the individual species, but it seems likely that they do not all react in the same way, and certainly they must influence one another as they thrive or decrease, so that the composition of the population will continually be changing. 


\section{Over-wintering of species of the loose-lying population}

In considering the question of how the various individual species composing the loose-lying population pass the winter months, one or two points may be noted.

(I) Some of the species do not survive. Acrothrix gracilis was dredged in quantity in the bay in 1950, but was not found at all in 1955. One small piece was found again in 1956.

(2) New species may appear. The source of these is at present not certain, but they may result from the practice of the local fishermen of throwing stones and boulders, caught in their nets, into the bay on the inner side of the breakwater. No information is available as to whether species could come from outside the bay as reproductive cells, or as small pieces of thallus travelling in the sea water.

(3) For those species occurring, not only in the loose-lying population, but also in the intertidal and/or in the sublittoral permanent population, e.g. Laminaria saccharina and Saccorhiza polyschides, plants for the following season could be obtained from these sources. It is interesting, however, that the four larger brown algae which form the bulk of the loose-lying population, Laminaria saccharina, Saccorhiza polyschides, Chorda filum, and Desmarestia aculeata, all have the same type of life history, involving an alternation between a large and structurally complex sporophyte and an exceedingly minute gametophyte. Samples of sand and gravel, as well as small stones collected at intervals during the winter months and kept in culture, all yielded young Laminaria sporophytes within a few weeks, as did also fragments of algae collected with the stones. This suggests that gametophytes are formed in such large numbers that they cover every available substrate, giving a continuous supply of plants for the loose-lying population.

Fragments of plants of many species were found in samples collected during January and February, many of them in a fruiting condition. The fragments were subjected to culture experiments and stages found in culture were searched for in the field at the same time. This procedure gave information on the way in which some of the individual species pass the winter. A few examples will be given from species for which the evidence is sufficiently complete to form a picture of the overwintering method. Much work remains to be done on these lines before anything like a complete picture can be obtained of the population as a whole.

\section{CULTURE TECHNIQUES}

In the culture experiments described below, the plants have been grown in an enriched Erdschreiber solution in glass troughs suspended in constanttemperature culture tanks. The tanks are lighted from above by lamps fixed into movable canopies and both $300 \mathrm{~W}$. filament bulbs, and Atlas Daylight 
fluorescent tubes are used as alternative light sources. Throughout the experiments the temperature has been maintained at $10^{\circ} \mathrm{C}$, and a day length of I $8 \mathrm{~h}$ has been used. The cultures have been aerated by bubbling air through the culture medium. The medium used has been Erdschreiber (Føyn, 1934) enriched by the addition of 'Tris' (Hydroxymethyl-amino-methane), the disodium salt of Ethylene-diamine-tetra-acetic acid, Vitamin Mix $\mathrm{S}_{3}$, and the range of trace elements in the concentrations given in the marine medium $\mathrm{ASP}_{2}$ of Provasoli, McLaughlin \& Droop (I957). I am grateful to Dr Provasoli for sending the formula for this medium to me and allowing me to use it before it was published.

\section{A GENERAL CULTURE EXPERIMENT}

Six stones each bearing, apparently, only one or two small plants of $L$. saccharina were taken from a dredge sample from the bay in September 1956. The Laminaria plants were cut back to a length of about $3 \mathrm{~cm}$ above the short stipe, and the stones were kept in culture throughout the winter months, during which time the plants increased to a length ranging from 25 to $30 \mathrm{~cm}$ but did not form sporangia. By the beginning of April 1957, the following algae had appeared attached either directly to stones or to the haptera of the Laminaria plants: enormous numbers of Laminaria sporelings some of which were large enough to be identified as L. saccharina, sporelings of Saccorhiza polyschides, Asperococcus bullosus (unilocular sporangia), Cladostephus verticillatus, Ectocarpus sp. (plurilocular sporangia), Ulva lactuca, Chaetomorpha melagonium, Enteromorpha clathrata, Rhodomela confervoides, Bonnemaisonia hamifera (tetrasporophyte), and Polysiphonia sp.

Only diatoms appeared on control stones kept in the same culture medium under similar conditions in a second glass trough. If six small stones taken at random from the floor of the bay in this way could produce a population of this kind in culture, presumably from reproductive bodies or juvenile stages already present attached to the stones in the autumn, the source of the sublittoral population for the following year is not far to seek.

It is interesting that Rhodomela confervoides appeared on the stones in this culture experiment. This alga is found frequently in the intertidal region and was plentiful in the sublittoral loose-lying population during the summers of both I955 and 1956. It was found also in dredge samples in January I956 as unattached broken fronds which had lost all secondary branches and were so ragged in appearance as to be hardly recognizable. Arising from the denuded main axes, however, were large numbers of very short erect branches ending in dense tufts producing tetrasporangia. Almost frondless midribs of Delesseria sanguinea producing tetrasporic branches in enormous numbers were also found in the same dredge sample and it is possible that other red algae behave in a similar manner in the deeper waters of the bay during the winter. If algae are able to reproduce freely in this way in the sublittoral, 
this region may be extremely important in acting as a source of new populations for the intertidal region also. Much more detailed work, however, would be required to establish this as an ecological principle.

\section{Laminaria saccharina INDIVIDUAL SPECIES}

The life history of L. saccharina includes two distinct morphological phases, a structurally elaborate diploid plant alternating with an extremely minute gametophyte, the latter consisting of a branched filament of a few cells, sometimes reduced to a single cell (Williams, I921; Harries, I932). Parke (1948) reported, as a result of her investigations, that 'sporophytes of Laminaria saccharina can be produced in nature during all months of the year at some level of the shore,.... The gametophyte generation of the species must, therefore, be capable of reproduction during all months of the year'. In the sublittoral zone, I-4 $\mathrm{m}$ below E.L.W.S.T., Parke reports cessation of sporophyte development from November to February. She suggests that this is due to low light intensity. Parke gives the region in the sublittoral zone of 6-I2 m below E.L.W.S.T. as a habitat in which no development of young plants was obtained on prepared surfaces. She remarks, however, that well developed plants of $L$. saccharina have been brought up from depths down to $12 \mathrm{~m}$ and suggests that, since these were growing on shingle, they may have been washed down into deeper water, having started their development in shallower water.

Sporelings of L. saccharina have been found in samples taken from the floor of Port Erin Bay during all months of the year. There seems little doubt that sporophyte production occurred on quite a large scale at depths down to I $4 \mathrm{~m}$ here during the winter of $1955-56$. A dredge sample taken across the bay at the end of January 1956 included the following: (I) plants of $L$. saccharina with the previous year's frondage attached to new frondage. The plants had either no apparent attachment or they were attached to stones and shells. Some had obviously been torn away from a rock surface, but had new hapteron branches attached to small stones, suggesting that this latter attachment had developed while the fronds were lying on the bottom gravel; (2) very small plants attached to stones and other algae; (3) broken pieces of large plants.

Both whole fronds and also broken pieces were found with ripe sporangia. Zoospores were released and allowed to settle in sea water on glass slides in glass dishes which were kept covered in a dim light in a constant temperature room at $10^{\circ} \mathrm{C}$. Later the dishes were transferred to the constant temperature culture tank at $10^{\circ} \mathrm{C}$, again under a low light intensity. The zoospores germinated to give both male and female gametophytes. In the female gametophytes no branched filaments were formed. The development was similar to that described by Williams (I9I2) and Harries (I932) as sometimes occurring in this species. After the zoospore had settled, a germination tube 
grew out and the contents of the spores passed into its swollen end which was then cut off by a wall. The swollen cell, which Harries described as the 'effective plant' functioned directly as an oogonium. Harries's work suggested that this might have been the effect of the culture conditions in which a fairly low temperature and a low light intensity were used, a high temperature and light intensity inducing a filamentous form in the gametophyte. Although no idea has yet been obtained of the exact conditions at the bottom of the bay, the temperature and light levels during the winter months would certainly have been below those used in the culture experiments. Fertilization was not observed, but since male gametophytes producing antheridia were also present on the same slides, it may actually have occurred. Since, however, young sporophytes were observed to be developing before any antheridia were seen, there is a possibility that parthenogenesis may have occurred. This has been recorded for L. saccharina by Schreiber (1930), though his haploid sporophytes showed an abnormal development. Since the zoospore can act directly as an oogonium and the male gametophytes are exceedingly small, a particle as small as a sand grain would be sufficient to provide attachment for the growth of the new sporophyte. Zoospores are produced in enormous numbers by the mature sporophytes so that, given suitable conditions of temperature and light intensity, and if undisturbed too greatly by water movements, there is the potentiality for the production of a large sublittoral population of L. saccharina. That this does, in fact, happen was shown by the presence, in samples taken at the end of March by dredge, of large numbers of sporelings of varying sizes, attached to sand grains and to small and large stones and to other algae. The range of size of frond found suggested that sporophyte production had proceeded throughout the winter. That a proportion of the sporophytes, even including some of very small size, had started to develop the previous autumn, was shown by a distinction in the fronds between narrow and broad regions of growth. A period of more active vegetative growth is reported by Parke (I948) to begin in January and the autumn and spring regions of growth can be distinguished by a marked difference in width in the frond. Since the young sporophytes were found in dredge samples, the exact depth from which they were taken could not be determined, but their presence on one or two large boulders taken in a position close to the seaward end of the breakwater suggests that they can develop at a depth approaching I4 $\mathrm{m}$.

In culture the developing sporophytes were removed from the slides as soon as they had reached a size of between 0.5 and I cm and were large enough to handle and they were left lying loose in the culture solution. They continued to develop, and by May 1957 had reached a maximum length of $30 \mathrm{~cm}$ and a width of $8 \mathrm{~cm}$. The total amount of frondage formed during this period was, however, greater than is indicated in this length measurement since decayed frondage was cast at the free end, while new tissue was added from 
the meristem above the stipe. It is of particular interest that the haptera of these plants have developed many branches and appear in all respects similar to those found on plants in the loose-lying population suspected of having developed unattached on the floor of the bay (Fig. I). It appears therefore that, except in the very earliest stages of the development of the sporophyte, an attachment to a substrate is not necessary for the growth of L. saccharina. That the free hapteron branches can become secondarily attached to a substrate is suggested by systems of the type in which each branch is attached separately to a small stone or shell.
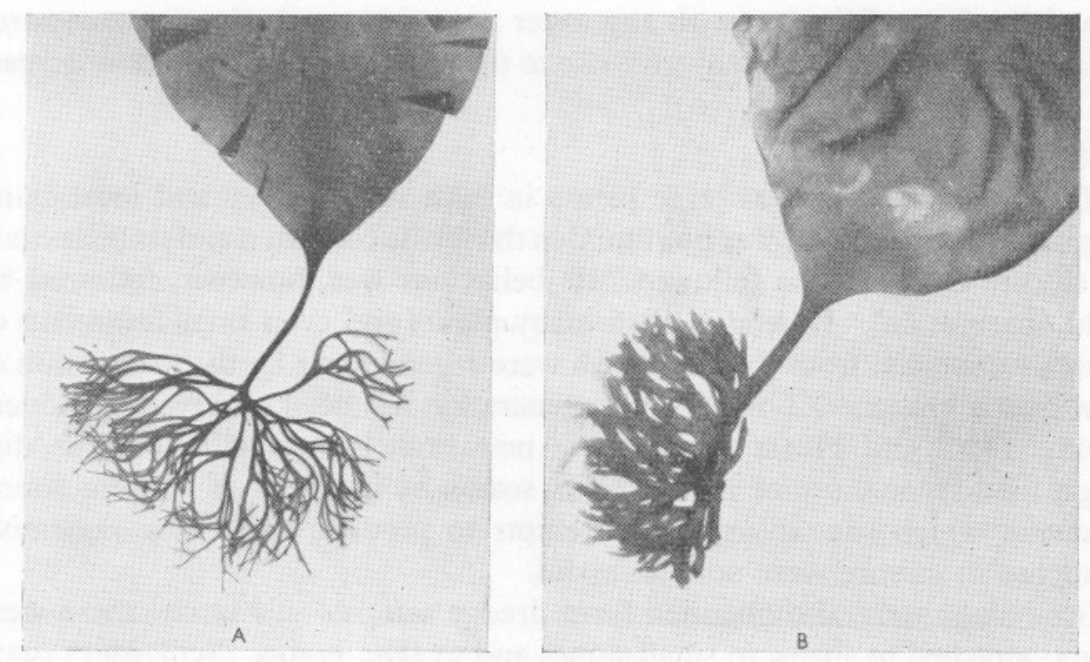

Fig. I. Hapteron systems of Laminaria saccharina (L.) Lamour. A, plant from loose-lying population (from herbarium sheet) $\times \frac{2}{9}$; B, plant grown unattached in culture $\times \frac{2}{3}$. Photos J. H. Bloor.

\section{Saccorhiza polyschides}

Spence (I9I8) reports that for the Orkney Islands, during the winter months the fronds of $S$. polyschides are washed ashore, but that the attaching 'bells' which become very firmly attached to the substrate, remain behind. Possibly this also happens in the sublittoral permanent population in Port Erin Bay, but it was not possible to find them. Samples taken in the winter months here showed that, while the majority of the mature plants, together with the stipes carrying the reproductive frills, had disappeared, there were still many basal bells lying loose on the floor of the bay. Some of these were dredged in January 1956, dark with sporangia all over the surface of the wart-like projections. Zoospores were released from these and allowed to settle on slides which were kept in culture in the laboratory. Male gametophytes were formed as short slender branched filaments, but, as with Laminaria saccharina, there 
was a tendency for the female gametophyte to be represented by a single cell: the first division cut off a cell which behaved as an oogonium developing directly into a new sporophyte. Fertilization was not observed. By March the sporophytes had reached a length of 3-4 cm. Sampling by dredge in Port Erin in March produced similar sporophytes in large numbers on stones and other algae. Some of the sporophytes found in the field were larger than those grown in culture, but many were at the same stage of development. Probably for Saccorhiza polyschides the attaching bell is of greater importance as a reproductive structure than the frill to the stipe which disappears earlier in the autumn with the blade of the plant. Such loose-lying bells, rolling round the floor of the bay with any water movement and releasing zoospores in large numbers, could easily give rise to the population for the ensuing year.

\section{Desmarestia aculeata}

D. aculeata occurred as large plants in both rock surface and loose-lying populations. This plant was not found in the fertile condition and its behaviour in culture could not be followed. Its behaviour was, however, followed by field observations. In March 1956 many plants and even small fragments of plants were taken from the bay which were regenerating by the production of new lateral branches. This type of regeneration has been observed by Söderström (I889) and Printz (I926). The new branches could readily be distinguished from those of the previous season by the tufts of delicate lateral branches which later disappear. Attempts to produce these new vegetative branches in culture were not successful.

Sporelings were also obtained from dredge samples in March: these were found attached to shells, to small stones and to sand grains. Schreiber (I932) has shown that the zoospores released by adult fronds give rise to filamentous gametophytes bearing oogonia and antheridia; and it may be assumed that these are formed on stones and shells and sand grains on the sea floor, sporelings later arising from them.

This plant therefore appears to have two distinct methods of building up its numbers for the following year, first, by regeneration from old plants and fragments of plants and, secondly, by the completion of its dimorphic lifehistory at the bottom of the bay.

\section{DISCUSSION}

To determine the behaviour of the sublittoral loose-lying population as a whole, one must know the behaviour of its component species and the interrelationships between them, and autecological studies will have to be made on the majority of its species. The composition of the population undoubtedly changes from time to time, both in the identity of the component species and also in their relative abundance. Changes in the conditions to which the 
population is subjected will almost certainly affect different species in different ways and the species themselves will affect one another by their absence or presence and abundance. Since the sublittoral loose-lying population has many species in common with that of the sublittoral rock-surface and intertidal areas, it is likely that there are complex interactions between the three regions. A slight indication that this is so is given by the fact that some species, as for example Rhodomela confervoides, occurring frequently in the intertidal region, can reproduce freely in the deeper parts of the bay during the winter months. The evidence given in this paper suggests that a detailed knowledge of the requirements and behaviour of algae in the sublittoral region will help towards an understanding of the ecology, not only of this, but also of the intertidal region.

I am much indebted to the Council of the Royal Society for a grant from the Browne Research Fund towards the cost of the survey, and I wish to thank Prof. N. A. Burges for help and encouragement throughout the course of the work. The work was carried out from the Marine Biological Station in Port Erin, and I should like to thank the Director, Mr J. S. Colman and his Staff, particularly Mr A. B. Bowers and Dr J. Kain, for their help in many ways: also Mr J. Faragher and Mr L. Collister, the crew of the 'Cypris'. The spring grab was loaned by the Institute of Seaweed Research, Musselburgh, by kind permission of the Director, Dr F. N. Woodward and I should also like to thank Mr F. T. Walker for much help and advice on the use of the grab for this survey work. Dr P. S. Dixon was responsible for the echo-sounding of the bay and $\mathrm{Mr} \mathrm{N}$. Hawkins of the Liverpool Sub-Aqua Club made the dives to check the grab. The following helped with the field work either in 1955 or I956 or in both years: Mr B. Appleby, Miss M. Beaumont, Mr J. Chubb, Mrs P. S. Dixon, Miss J. Hawkins, Mr B. Kendrick, Mr I. Prestt and Mr G. Strafford. My thanks are due to all of these people for their help.

\section{SUMMARY}

A combination of dredge, grab and diving techniques was used to make a survey of the sublittoral algae of Port Erin Bay, Isle of Man. Two distinct populations were found, one attached to the rock surface on the sides of the bay and the other more or less loose-lying on its sandy floor.

The loose-lying population is conspicuous only during the summer months, usually from July until October, and is washed up on to the beach by storms or decays on the floor of the bay.

Culture experiments combined with field observations at different times of the year have been used to determine the overwintering methods of some of the individual species of the loose-lying population. For two of the dominant species, Laminaria saccharina and Saccorhiza polyschides, both of which are 
extreme dimorphic diplohaplonts, it has been shown that gametophytes are formed in extremely large numbers on all possible substrates on the floor of the bay during the winter and give a continuous supply of young sporophytes to renew the population.

\section{REFERENCES}

AleEM, A. A., I956. A quantitative study of the benthic communities inhabiting the kelp beds off the California coast, with a self-contained diving apparatus. 2nd Intern. Seaweed Symp., pp. I49-52. London: Pergamon Press.

Burrows, E. M. \& LodGe, S. M., I949. Note on the interrelationships of Patella, Balanus and Fucus on a semi-exposed coast. Rep. mar. biol. Sta. Pt Erin, No. 62, pp. $30-4$.

- 1951. Autecology and the species problem in Fucus. F. mar. biol. Ass. U.K., Vol. 30, pp. 16I-76.

BURSA, A., WojTUSIAK, H. \& WojTUSIAK, R., 1939. Untersuchungen über die Bodenfauna und Bodenflora der Danziger Bucht unter Anwendung eines Taucherhelms. Bull. int. Acad. pol., Cracovie, Ser. B II, 1939, pp. 6I-97.

- 1948. Investigations of the bottom fauna and flora in the Golf of Gdańsk made by using a diving helmet. Part II. Bull. int. Acad.pol., Cracovie, Ser. B II, 1948, pp. 213-39.

ForsteR, G. R., 1955. Underwater observations on rocks off Stoke Point and Dartmouth. F. mar. biol. Ass. U.K., Vol. 34, pp. I97-9.

- 1958. Underwater observations on the fauna of shallow rocky areas in the neighbourhood of Plymouth. F. mar. biol. Ass. U.K., Vol. 37, pp. 473-82.

Føyn, B., 1934. Lebenszyklus, Cytologie und Sexualität der Chlorophyceen Cladophora suhriana Kützing. Arch. Protistenk., Bd. 83, pp. I-56.

HARRIES, R., 1932. An investigation by cultural methods of some of the factors influencing the development of the gametophyte and the early stages of the sporophyte of Laminaria digitata, L. saccharina and L. cloustoni. Ann. Bot., Lond., Vol. 46, pp. 893-928.

JoNES, N. S., I948. Observations and experiments on the biology of Patella vulgata at Port St Mary, Isle of Man. Proc. Lpool biol. Soc., Vol. 56, pp. 60-77.

Kitching, J. A., MACAN, T. T. \& Gilson, C. H., I934. Studies in sublittoral ecology. I. A submarine gully in Wembury Bay, South Devon. F. mar. biol. Ass. U.K., Vol. 19, pp. 677-706.

Knight, M. \& Parke, M., I93i. Manx Algae. Mem. Lpool mar. biol. Comm., No. 30.

- 1950. A biological study of Fucus vesiculosus L. and F. serratus L. F. mar. biol. Ass. U.K., Vol. 29, pp. 439-5I4.

LODGE, S. M., I948. Algal growth in the absence of Patella on an experimental strip of foreshore, Port St Mary, Isle of Man. Proc. Lpool biol. Soc., Vol. 56, pp. 79-83.

- 1954. Sublittoral algal communities in the Isle of Man. Rap. Comm. 8th Inter. Con. Bot. Paris, pp. 139-40.

NAYLOR, E., I955. The ecological distribution of British species of Idotea (Isopoda). F. Anim. Ecol., Vol. 24, pp. 255-69.

PARKe, M., I948. Studies on British Laminariaceae. I. Growth in Laminaria saccharina (L.) Lamour. F. mar. biol. Ass. U.K., Vol. 27, pp. 651-709.

- 1953. A preliminary check-list of British marine Algae. 9. mar. biol. Ass. U.K., Vol. 32, pp. 497-520.

- A preliminary check-list of British marine Algae. Corrections and additions Phycolog. Bull., No. 4, pp. 26-31. 
PARKE, M., A preliminary check-list of British marine Algae. Corrections and additions, II. Phycolog. Bull., No. 5, pp. 36-37.

Printz, H., I926. Die Algenvegetation des Trondjemsfjordes. Skr. norske VidenskAkad. Bd. I, No. 5, pp. I-273.

Provasoli, L. Mclaughlin, J. J. A. \& Droop, M. R., 1957. The development of artificial media for marine algae. Arch. Mikrobiol., Bd. 25, S, p. 408.

SCHREIBER, E., I930. Untersuchungen über Parthenogenesis, Geschlechtsbestimmung und Bastardierungsvermögen bei Laminarien. Planta, Bd. I2, Heft 3, pp. $33 \mathrm{I}-53$.

SCHREIBER, E., I932. Úber die Entwicklungsgeschichte und die systematische Stellung der Desmarestiaceen. Z. Bot., Bd. 25, pp. 56I-82.

SöDERSTRÖM, E., I889. Ueber die anatomischen Bau von Desmarestia aculeata (L.) Lam. Bih. svensk. VetenskAkad. Handl., Bd. I4, Afd. 3, No. 3, I6 pp.

Southward, A. J., 1953. The ecology of some rocky shores in the south of the Isle of Man. Proc. Lpool biol. Soc., Vol. 59, pp. I-50.

SPENCE, M., I918. Laminariaceae of Orkney. Their ecology and economics. F. Bot., Lond., pp. 28I-5.

WeARN, M. I952. Rocky-shore algae in the Öregrund Archipelago. Acta phytogeogr. suec., Bd. 30, Uppsala.

WALKER, F. T., I947. Sublittoral seaweed survey. F. Ecol., Vol. 35. pp. I66-85.

Williams, J. LloYD, I9I2. The zoospores of the Laminariaceae and their germination. Rep. Brit. Ass., Dundee, p. 685.

- I92I. The gametophytes and fertilization in Laminaria and Chorda. (Preliminary Account). Ann. Bot. Lond., Vol. 35, pp. 603-7. 